\title{
Hideaki Kami, Diplomacy Meets Migration: US Relations with Cuba during the Cold
}

War. Cambridge: Cambridge University Press, 2018. xiv + 36o pp. (Cloth US\$49.99)

Despite the last 60 years of hostility between Cuba and the United States, the two countries have repeatedly engaged in diplomatic negotiations. The subject continually embedded in this dialogue has been migration. Even during the Trump administration, when relations became more tense than they were during the final two years of Barack Obama's presidency, Cuban and U.S. officials have met semi-annually to discuss implementation of the 1995 immigration accord. This phenomenon offers the rationale for the focus of Diplomacy Meets Migration, which examines the impact that migration and migrants had on Cuban-U.S. relations during the Cold War.

Hideaki Kami provides a richly detailed study of the relationship based on an extensive use of multicountry archives, memoirs, and interviews with some key decision makers. Much of the territory has already been well covered in Lars Schoultz, That Infernal Little Cuban Republic (2009) and William LeoGrande and Peter Kornbluh, Back Channel to Cuba (2014). Yet Kami's prodigious research effort has unearthed gems that glitter throughout the book, contributing important information to our understanding of Cuban-U.S. relations. For example, he found that during the so-called Mariel exodus in 1980, the Voice of America focused more attention on Cuban emigration than on the Soviet invasion of Afghanistan, in order to discredit the Cuban Revolution.

One of the book's strengths is its extensive account of the many deadly terrorist attacks Cuban exiles committed over several decades, at the direction of, or with the support of, the U.S. government, or as a consequence of U.S. unwillingness to crack down on terrorists, creating an atmosphere that tolerated terrorist acts against Cubans. Still, as Kami demonstrates, Cuba favored dialogue with the United States over confrontation throughout much of the Cold War. Even after exile terrorists blew up a Cuban civilian airliner in 1976, killing all 73 people on board, Cuba sought to reopen a dialogue with President Gerald Ford's administration.

The U.S. record of terrorism has been a major source of Cuban distrust about its adversary's intentions, and the U.S. failure even to apologize for its behavior was an obstacle to improved relations during the Cold War. Kami's recognition of this obstacle is indicative of how well he understands Cuba's point of view and how well Diplomacy Meets Migration succeeds in presenting both the U.S. and Cuban perspectives. It also succeeds in its aim of contributing to the current wave of global histories that have accorded agency to small states. Kami offers a thoughtful and provocative argument that disputes the conventional narrative of U.S.-Latin American conflict, which portrays a hegemonic United 
States clashing with counterhegemonic Latin Americans. In the Cuban case, he asserts, the analysis is more complex as Cuban counterrevolutionaries sought to use U.S. hegemonic power to reclaim their own control over the island.

However, the book's overall analysis is both questionable and inadequately sustained by the evidence it presents. This weakness is most glaring in the two chapters on the Reagan administration. Even though Kami acknowledges that U.S. officials were most concerned at the time about Cuba's support for the Nicaraguan and Angolan governments and the rebels in El Salvador, he attributes considerable influence to the Cuban American National Foundation (CANF) over U.S. policy toward Cuba. Yet the CANF had only limited successessentially frightening some U.S. senators and members of Congress away from support for anti-embargo legislation. Relying too heavily on CANF archives, Kami counts the creation of Radio Martí as a CANF victory when it would have been more appropriately described as the result of pushing on an open door. The idea for the propaganda radio station, as he notes, came from Roger Fontaine, Reagan's first national security advisor for Latin America.

Laudably, Kami provides some details about the CANF from its archives that have not been previously available to an English-speaking audience. But he discounts the significant role the Reagan administration had in making the CANF into a force that had its greatest impact after the Cold War. He ignores the fact that one reason CANF board members were able to "generously" contribute large sums to the organization was due to the lucrative government contracts their companies began to garner during the Reagan years.

Ultimately, the thesis of Diplomacy Meets Migration that migration is the best lens through which to view U.S.-Cuban relations during the Cold War is unconvincing. While the book has many merits, the sum of the whole is less than the quality of its parts.

\author{
Philip Brenner \\ School of International Service, American University \\ pbrenne@american.edu
}

